\title{
Genomic imprinting and cancer
}

\author{
J A Joyce, P N Schofield
}

\begin{abstract}
Genomic imprinting is the phenomenon by which individual alleles of certain genes are expressed differentially according to their parent of origin. The alleles appear to be differentially marked during gametogenesis or during the early part of development. This mark is heritable but reversible from generation to generation, implying a stable epigenetic modification. Approximately 25 imprinted genes have been identified to date, and dysregulation of a number of these has been implicated in tumour development. The normal physiological role of many imprinted genes is in the control of cell proliferation and fetal growth, indicating potential mechanisms of action in tumour formation. Both dominant and recessive modes of action have been postulated for the role of imprinted genes in neoplasia, as a result of effective gene dosage alterations by epigenetic modification of the normal pattern of allele specific transcription. The aim of this review is to assess the importance of imprinted genes in generating tumours and to discuss the implications for novel mechanisms of transforming mutation.

(F Clin Pathol: Mol Pathol 1998;51:185-190)
\end{abstract}

Keywords: genomic imprinting; cancer; chromosome 11; loss of imprinting; tumour suppressor gene

Dr Joyce.

email:

JAJ@mole.bio.cam.ac.uk

Accepted for publication 11 June 1998
Weidemann syndrome ${ }^{1}$ and to hereditary glomus tumours ${ }^{2}$ in similar pedigrees had long been puzzling, as penetrance appeared to be most complete for transmission through one of the two parental sexes. However, such a pattern of inheritance can be reconciled with a model in which the familial mutation is present in an imprinted gene, and penetrance is only seen when a recessive lesion is inherited from the parent whose allele would normally be expressed, rendering the individual effectively nullizygous for a tumour suppressor locus. Alternatively, the observed pattern might be explained by a dominant tumour growth enhancing factor, whose normally suppressed allele is activated by mutation.

The development of hereditary glomus tumours or paragangliomas only occurs when the mutant locus is inherited paternally. ${ }^{3}$ The disease maps to two loci on chromosome 11, $11 \mathrm{q} 13.1$ and $11 \mathrm{q} 22.3-11 \mathrm{q} 23.3$, both of which appear to be imprinted, although the genes have yet to be identified. ${ }^{245}$

The first concrete evidence that imprinted genes might be involved directly in tumorigenesis came from the observation of an absolute bias (95-100\%) in the loss of $11 \mathrm{p} 15$ maternal alleles, as indicated by loss of heterozygosity (LOH) in Wilms' tumours and embryonal rhabdomyosarcoma ${ }^{67}$ Selective maternal allele loss has now been documented in other childhood tumours-adrenocortical carcinoma and hepatoblastoma - as well as in adult cancers of the breast, bladder, ovary, kidney, and testis (table 1). Consistent LOH for a particular chromosome or locus is a strong indication that

Table 1 Alterations in imprinted genes in various human cancers

\begin{tabular}{|c|c|c|c|c|c|c|c|c|c|c|c|}
\hline Cancer & $\begin{array}{l}\text { Pref. } \\
\text { maternal } \\
11 p 15 \\
\text { LOH }\end{array}$ & $\begin{array}{l}I G F 2 \\
L O I\end{array}$ & $\begin{array}{l}I G F 2 \\
m R N A \\
\text { increase }\end{array}$ & $\begin{array}{l}\text { H19 } \\
\text { LOI }\end{array}$ & $\begin{array}{l}\text { H19 } \\
m R N A \\
\text { decrease }\end{array}$ & $\begin{array}{l}\text { H19 } \\
\text { mRNA } \\
\text { increase }\end{array}$ & $\begin{array}{l}p 57^{K I P 2} \\
L O I\end{array}$ & $\begin{array}{l}p 57^{K I P 2} \\
m R N A \\
\text { decrease }\end{array}$ & $\begin{array}{l}6 q \\
\mathrm{LOH}\end{array}$ & $\begin{array}{l}\text { IGF2R } \\
\text { mutations }\end{array}$ & References \\
\hline Wilms' tumour & + & + & + & + & + & & + & + & ND & ND & $7-15$ \\
\hline Adrenocortical carcinoma & + & + & + & ND & + & & ND & + & ND & ND & $16-19$ \\
\hline Rhabdomyosarcoma & + & + & + & - & + & & ND & ND & ND & ND & $6,18,20-23$ \\
\hline Hepatoblastoma & + & + & ND & - & + & & ND & ND & ND & ND & $24-26$ \\
\hline Hepatocellular carcinoma & + & + & ND & + & & + & ND & $\mathrm{ND}$ & + & + & $18,27-31$ \\
\hline Breast cancer & + & + & + & ND & ND & ND & ND & ND & + & + & $18,32-36$ \\
\hline Lung cancer & + & + & + & + & & + & ND & ND & + & ND & $18,33,37-41$ \\
\hline Colorectal cancer & ND & + & + & - & ND & ND & ND & ND & ND & + & 42,43 \\
\hline Leiomyosarcoma & ND & + & ND & - & ND & ND & ND & ND & ND & ND & 44 \\
\hline Testicular germ cell cancer & + & + & ND & + & ND & ND & ND & ND & ND & ND & $18,45,46$ \\
\hline Renal cell carcinoma & ND & + & + & - & ND & ND & ND & ND & + & ND & 47,48 \\
\hline Endometrial cancer & ND & ND & ND & ND & ND & ND & ND & ND & ND & + & 42 \\
\hline Kidney clear cell sarcoma & ND & + & + & ND & ND & ND & ND & ND & ND & ND & 49 \\
\hline Choriocarcinoma & ND & + & + & + & & + & ND & + & ND & ND & $50-53$ \\
\hline Cervical carcinoma & ND & + & ND & + & ND & & ND & ND & + & ND & 54,55 \\
\hline Oesophageal cancer & ND & + & + & + & & + & ND & ND & ND & ND & 56,57 \\
\hline Bladder cancer & + & ND & ND & ND & & + & ND & ND & ND & ND & 18,58 \\
\hline Acute myeloid leukemia & ND & + & ND & ND & ND & ND & ND & ND & ND & ND & 18,59 \\
\hline Gastric cancer & ND & + & + & - & - & & ND & ND & + & ND & $42,60-62$ \\
\hline Glioma & ND & + & ND & - & ND & ND & ND & ND & + & ND & 63,64 \\
\hline Ovarian carcinoma & ND & - & + & ND & ND & ND & ND & ND & + & ND & $48,65,66$ \\
\hline Neuroblastoma & ND & - & ND & - & ND & ND & ND & ND & ND & ND & 67 \\
\hline
\end{tabular}

The categories used are: pref. maternal 11p15 LOH, preferential maternal 11 15 loss of heterozygosity; IGF2 LOI, IGF2 loss of imprinting; IGF2 mRNA increase; H19 LOI, H19 loss of imprinting; H19 mRNA increase or decrease; $p 57^{K I P 2}$ LOI, $p 57^{K I P 2}$ loss of imprinting; $p 57^{K I P 2}$ mRNA decrease; $6 q$ LOH, loss of heterozygosity on chromosome $6 q ;$ IGF2R mutations, mutations detected in the IGF2R gene. Classifications are based on more than one positive report in each category and the primary publications are referenced. 
there might be a tumour suppressor gene located within the smallest common deficiency. Tumour suppressors are usually inactivated sequentially on both alleles according to Knudson's "two hit" hypothesis. ${ }^{68}$ In the case of maternally expressed tumour suppressor genes, the "first hit" is the imprinting or inactivation of the paternal allele and the preferential maternal $\mathrm{LOH}$ observed is equivalent to the "second hit". Thus, the effective constitutive hemizygosity, resulting from epigenetic silencing of one allele, is the normal state, rather than the result of a predisposing genetic mutation, as originally envisaged by Knudsen and Strong.

In the case of $11 \mathrm{p} 15.5$, the parental bias of allele loss in tumours suggests either the loss of a maternally active tumour suppressor gene, or the acquisition of a paternally expressed growth promoting factor through duplication of the expressed copy. In support of the former hypothesis, three groups have transferred subchromosomal fragments from this region into rhabdomyosarcoma and Wilms' tumour cell lines and assayed the potential of these fragments to suppress in vivo tumorigenicity in nude mice. ${ }^{69-71}$ These combined studies demonstrate the presence of a potential tumour suppressor gene(s) within a 500 kilobase $(\mathrm{kb})$ region of $11 \mathrm{p} 15.5$. Alternatively, or additionally, it is possible that preferential loss of maternal alleles is driven by the selective advantage of acquiring a double dose of a paternally active factor by gene duplication, which promotes tumour cell growth. Although the identity of the putative tumour suppressor at $11 \mathrm{p} 15.5$ is as yet unknown, a strong candidate for a tumour growth promoting factor is insulin-like growth factor II (IGF-II); the gene encoding this factor maps to $11 \mathrm{p} 15.5$ and lies within a cluster of imprinted genes.

\section{Growth promoters at $11 \mathrm{p} 15$}

The role of the IGF system in tumour growth has been reviewed recently. ${ }^{72}$ The first observation of raised IGF-II concentrations in a neoplastic situation was made in a series of developmental tumours, where expression of the IGF2 gene was greatly enhanced (up to 50 fold) with respect to the age matched normal tissue, and comparable to that seen in earlier phases of development. ${ }^{8}$ The observation that a fetal growth related pattern of growth factor expression is not extinguished during tissue differentiation suggests that this is an example of "oncofetal" gene expression. More recently, the observation of enhanced IGF2 expression in a wide variety of adult tumours suggests that there might be a clear selective advantage in high levels of expression of this gene. Interestingly, concentrations of IGF-I are raised much more rarely, although the type 1 receptor, through which both factors act, is often present at increased concentrations in tumours. ${ }^{73}$ However, the latter is not imprinted in humans or mice. ${ }^{74}$ Genetic ablation of the type 1 receptor has been shown to abrogate the effects of a variety of transforming agents, such as simian virus 40 (SV40) $\mathrm{T}$ antigen ${ }^{75}$ and other oncogenes, suggesting that, although the IGFs do not act as classic transforming growth factors, their action might be essential to allow the full transforming potential of other oncogenes. Accumulating evidence suggests a role for IGF-II in cell survival and suppression of apoptosis, a mechanism of action supported by experiments in vivo. ${ }^{76}$ Activation of IGF2 expression seems to be an early event in some systems, and has been shown to contribute towards tumour growth by reducing apoptosis during the preneoplastic phase of pancreatic $\beta$ cell transformation in a transgenic model. ${ }^{77}$ Similarly, a high degree of expression has been shown in nephrogenic rests and in preneoplastic smooth muscle lesions, indicating that the time window during which IGF2 expression becomes raised might differ between tumour types. ${ }^{94}$

IGF2 is an imprinted gene, as first demonstrated in the mouse following gene knockout, ${ }^{78}$ and then in the human by direct analysis. ${ }^{79} 80 \mathrm{It}$ is expressed almost completely from the paternal allele (>95\%) during development and, therefore, breakdown in the normal suppression of the maternal allele by loss of imprinting (LOI), or duplication of the active paternal allele, are likely candidates for the mechanism increasing IGF2 expression; both effectively doubling the available transcriptional template. The first tumour in which this was observed was Wilms' tumour, where LOI for IGF2 and/or the adjacent gene $\mathrm{H} 19$ was reported in the majority of cases, most of which were early onset, implying that LOI of IGF2 was an early event in Wilms' tumorigenesis. ${ }^{10}{ }^{11} 81$ Significantly, in the tumour predisposing BeckwithWiedemann syndrome, IGF2 imprinting is constitutively relaxed, indicating that enhanced transcription might in itself predispose towards tumour growth, without being sufficient to initiate tumours alone, ${ }^{82} 83$ consistent with a scenario in which IGF2 expression acts to affect cell survival and, consequently, predisposes to the accumulation of further transforming mutations.

However, it is becoming clear that there is a discrepancy between LOI and an overall rise in IGF2 mRNA.${ }^{84}{ }^{85}$ For example, LOI of IGF2 is seen in Ewing's sarcoma but is not always associated with increased expression of IGF2 mRNA. ${ }^{86}$ Increased expression of IGF2 in Wilms' tumours and some hepatoblastomas is not always dependent on loss of genomic imprinting. ${ }^{67} 87$ It is also clear that LOI is not a prerequisite, even within one tumour category.

In addition, there are quantitative considerations to take account of because the general increase in IGF2 mRNA concentrations associated with LOI are usually greater than the expected $100 \%$ for a doubling of available template-for example, in leiomyosarcoma. ${ }^{88}$ This suggests either that additional nonimprinting dependent mechanisms are operating, or that in some way interallelic processes become active, and that these allow transsensing of active transcription and upregulate the process in both copies.

Although IGF2 is an excellent candidate for the key imprinted growth stimulatory gene in 
this part of the genome, loss of imprinting at IGF2 is by no means a prerequisite for tumour formation. IGF2 lies within a cluster of genes that are regulated coordinately by imprinting, including $\mathrm{H} 19$ and $\mathrm{p} 57^{\mathrm{KIP} 2}$ (CDKN1C). Therefore, it could be that the tumour suppressor and/or promoter activity suggested by genetic studies is the result of mutations in other closely linked genes, which are themselves additional candidates for contribution towards the neoplastic state.

\section{Tumour suppressors at $11 \mathrm{p} 15$}

H19

H19 maps to within $200 \mathrm{~kb}$ of IGF2, yet it is imprinted in the opposite direction, being expressed exclusively from the maternal allele. ${ }^{89}$ Alterations in $\mathrm{H} 19$ imprinting status and expression have been reported in a number of cancers (table 1) and it was initially proposed to be a tumour suppressor gene, based on two types of observations. Primarily, expression of $\mathrm{H} 19$ was found to be reduced, or even extinguished, in a proportion of Wilms' tumours and other tumours. ${ }^{12}{ }^{13}$ Secondarily, forced expression experiments initially supported a direct tumour suppressive effect of H19. ${ }^{90}$ The mechanism by which $\mathrm{H} 19$ might act as a tumour suppressor gene is not clear because the gene encodes an untranslated RNA of unknown function. ${ }^{91}$ Transfection of an H19 expression construct into the malignant G401 and rhabdomyosarcoma tumour cell lines generated altered cellular morphology, retarded growth, and reduced tumorigenicity ${ }^{91}$; however, discrepant results have been reported by other workers. ${ }^{71}$

The reciprocal pattern of imprinting to that of IGF2, suggested to be caused by enhancer competition between promoters of the two genes, ${ }^{92}$ frequently breaks down when IGF2 LOI occurs, both in neoplastic and nonneoplastic situations, indicating that $\mathrm{H} 19$ extinction is, as discussed above for IGF2 overexpression, not in itself necessary for the development of cancer. In support of this, Reid et al. found that H19 was expressed in several non-tumorigenic cell lines, but also in significant amounts in tumorigenic cell lines. ${ }^{71}$ Moreover, a discordantly high level of expression of $\mathrm{H} 19$ has also been reported in a number of human cancers including lung, oesophageal, and bladder carcinoma (see table 1 for full list). Recent data linking tumour progression with H19 expression confirms the suggestion that H19 LOI is either an epiphenomenon associated with locus specific or more global changes in imprinting control, or an example of oncofetal gene expression. ${ }^{27}$ In either case, a direct, causal link with tumour formation now looks unlikely.

p5 $7^{\mathrm{KIP} 2}$

$\mathrm{p} 57^{\mathrm{KIP} 2}$ is a member of the $\mathrm{p} 21$ family of cyclin dependent kinase inhibitors (CDKIs), which inhibit cell cycle progression by binding to the cyclin dependent kinases (CDKs) responsible for the G1/S transition. ${ }^{93}{ }^{94}$ However, $\mathrm{p} 57^{\mathrm{KIP} 2}$ is the only member of the CDKI families (which also include INK proteins) that is known to be imprinted, being expressed predominantly from the maternal allele. ${ }^{95} 96$ Because human p5 $7^{\mathrm{KIP} 2}$ maps to $11 \mathrm{p} 15.5$ and is maternally expressed, it is possible that it might be a tumour suppressor, with preferential maternal $\mathrm{LOH}$ resulting in a loss of $\mathrm{p} 57^{\mathrm{KIP} 2}$ expression.

It is intuitively easy to envisage how the loss of $\mathrm{p} 57^{\mathrm{KIP} 2}$ activity, a negative regulator of the cell cycle, could be responsible for the increased proliferative advantage of tumours in which it is inactivated. In addition, a recent study indicated that $\mathrm{p} 57^{\mathrm{KIP} 2}$ interacts with proliferating cell nuclear antigen (PCNA) a cofactor for the $\delta$ subunit of DNA polymerase, suggesting that this might be another pathway (in addition to CDK inhibition) that prevents cell proliferation. ${ }^{97}$

A reduction in $\mathrm{p} 57^{\mathrm{KIP} 2}$ expression has been noted in some Wilms' tumours ${ }^{15}{ }^{15}$ but, as yet, its expression and imprinting status have not been examined in a wide range of neoplasias. In two recent studies, the paternal allele of $\mathrm{p} 57^{\mathrm{KIP} 2}$ was found to be expressed in five of five ${ }^{98}$ and $10 \%$ of Wilms' tumours examined. ${ }^{99}$ Paradoxically, this was associated with an overall decrease in mRNA concentrations in all tumours in one study, ${ }^{99}$ suggesting that if p $57^{\mathrm{KIP} 2}$ does act as a tumour suppressor, the mechanism of transcriptional downregulation is dominant over the expected effects of loss of imprinting.

$\mathrm{P} 57^{\mathrm{KIP} 2}$ mutations have not been found in any of the tumours analysed to date (which have included soft tissue sarcomas, Wilms' tumours, liver, and lung cancers $)^{37} 99-101$ and in only $\sim 10 \%$ of patients with Beckwith-Weidemann syndrome (these mutations were present constitutively and were not associated with tumour development). ${ }^{102-104}$ In addition, $\mathrm{p} 57^{\mathrm{KIP} 2}$ expression was found in tumorigenic clones of the G401 cell line (as mentioned above for H19), indicating that at least in this assay it is unlikely to be responsible for suppression of tumorigenicity. ${ }^{105}$ Thus, it is still unclear whether $\mathrm{p} 57^{\mathrm{KIP} 2}$ is the elusive $11 \mathrm{p} 15.5$ tumour suppressor gene.

\section{RECENTLY IDENTIFIED CANDIDATE TUMOUR} SUPPRESSOR GENES

Subchromosomal fragment complementation assays have allowed the mapping of the gene(s) responsible for tumour suppressor function telomeric to D11S601, ${ }^{71}$ partially overlapping with a $3 \mathrm{Mb}$ region responsible for retardation of tumour growth. ${ }^{70}$ The region of overlap $(\sim 500 \mathrm{~kb})$ has been shown recently to contain a number of novel candidate tumour suppressor genes. At least two of these are known to be imprinted (IPL/TSSC 3 and BWR1A), whereas the other genes have not yet been characterised fully (TSSC1, TSSC2 and BWR1B). ${ }^{106-108}$ IPL/ TSSC 3 is homologous to the gene encoding the TDAG51 protein, which is involved in Fas mediated apoptosis, and BWR1A shows strong homology to the genes encoding the tetracycline resistance efflux proteins.

BWR1A was screened for mutations in various tumour cell lines (breast and lung carcinomas, rhabdomyosarcomas, Wilms', and rhabdoid tumours) and in patients with 
Beckwith-Weidemann syndrome. ${ }^{108}$ Two mutations were detected in two patients (a $111 \mathrm{bp}$ insertion in a breast cancer and a point mutation in a rhabdomyosarcoma). Because the mutation frequency was quite low, it is possible that BWR1A might be silenced by epigenetic inactivation, as is seen with $\mathrm{H} 19$, and possibly $\mathrm{p} 57^{\mathrm{KIP} 2}$. Indeed, this might also be the case for the new $11 \mathrm{p} 15.5$ genes, such as GOK, the loss of expression of which has been implicated recently in rhabdomyosarcoma. ${ }^{109}$ The mechanism by which it is repressed was suggested to be epigenetic because genetic alterations were not detected.

It is possible that these genes are regulated coordinately by an "imprinting centre", as has been postulated for the Prader-Willi and Angelman syndromes. ${ }^{110}$ Mutations that disrupt the imprinting centre could affect downstream genes resulting in loss of imprinting/loss of expression in the various $11 \mathrm{p} 15.5$ genes, as is seen in a large number of human cancers (table 1). It will be interesting to see if mutations (genetic or epigenetic) are found in the other candidate genes, particularly TSSC3, given the possibility that it might function in apoptosis.

\section{Other tumour suppressors}

IGF2R AND WT-1

The insulin-like growth factor type 2 receptor gene (IGF2R) is imprinted in the mouse, and is also expressed exclusively from the maternal allele. ${ }^{111}$ However, in humans it is polymorphically imprinted, and most of the population express IGF2R from both parental alleles. ${ }^{112}$ The chromosomal region to which IGF2R maps (6q26-27) frequently shows $\mathrm{LOH}$ in certain tumours (table 1), and it has been shown recently to be mutated in liver, breast, stomach, endometrial, and colorectal cancers. ${ }^{28324261}$ IGF2R is thought to be responsible both for extracellular IGF-II degradation and the trafficking of lysosomal enzymes. Gene ablation in transgenic mice leads to increased circulating concentrations of IGF-II, with concomitant overgrowth during development. ${ }^{113}$

The type 2 receptor is a multifunctional protein, also responsible for the activation of transforming growth factor $\beta$ (TGF $\beta)$, which in its active form can then inhibit growth by binding to TGF $\beta$ receptors in some cell types. ${ }^{114}$ Thus, loss or mutation of this gene would be predicted to result in an increase in extracellular IGF2 concentrations (stimulating growth) and a concomitant deficiency in activation of latent TGF $\beta$ (possibly preventing apoptosis and growth inhibition). Indeed, these predictions have been confirmed recently in gastric and colorectal cancers. ${ }^{115}$ In addition, recent evidence that IGF2R is mutated at early stages in liver and breast tumorigenesis supports the prediction that tumours in which IGF2R is mutated have a substantial selective growth advantage. ${ }^{29}$

Similar polymorphic imprinting is seen in the expression of the Wilms' tumour suppressor gene (WT1) located at $11 \mathrm{p} 13 .{ }^{116}$ In principle, populations in which WT-1 and IGF2R are imprinted should show an increased tumour incidence, or at least a differential involvement of these genes in the development of neoplasia. In support of this, a recent study reported that the paternal IGF2R allele was silenced in 50\% of Wilms' tumours. ${ }^{117}$ Although it is difficult to test the consequences for differential tumour susceptibility, responses to environmental factors, such as radiation, might have important consequences for the interpretation of epidemiological data concerning tumour incidence.

\section{Conclusions}

It is now becoming increasingly obvious that disruption of imprinting is common in a wide range of human cancers of both embryonal and adult origin. While much of the work to date has involved identification of the imprinted genes involved in cancer, the precise involvement of these genes in the tumorigenesis pathway needs to be elucidated. Importantly, the realisation that some mutations (imprinting centre mutations) might affect the imprinting of a cluster of genes, implies that in some cases concerted action by aberrently expressed growth promoters and suppressors might be important in key rate limiting processes during tumour formation.

Not only might imprinted genes be involved generally in the control of cell proliferation, but they might also constitute members of the same regulatory pathways; consequently, similar pathologies arising from different mutations might simply reflect the epistatic nature of the gene products in the same process. This implies that although we might see very similar phenotypic effects of mutations in this class of gene, the genes actually affected might differ between individual tumours or predisposing syndromes.

The possibility of both epistasis and coordinate regulation greatly complicate the task of interpreting the pathology resulting from dysregulation of imprinted genes, but our knowledge to date concerning the interactions between at least some of these genes suggests that it is precisely these complications that make our understanding of the role of imprinted genes in cancer so important.

The authors thank Dr A Ferguson-Smith for helpful comments on the manuscript. Related work in the authors' laboratory is funded by the Wellcome Trust, the BBSRC, and the Newton Trust.

1 Elliott M, Maher ER. Beckwith-Wiedemann syndrome. $\mathcal{f}$ Med Genet 1994;31:560-4

2 Struycken, PM, Cremers CWRI, Mariman ECM, et al. Glomus tumours and genomic imprinting: influence of Glomus tumours and genomic imprinting: influence of
inheritance along the paternal or maternal line. Clin inheritance along the pater

3 Mariman ECM, Vanbeersum SEC, Cremers CWRJ, et al. Fine mapping of a putatively imprinted gene for familial nonchromaffin paragangliomas to chromosome 11q13.1evidence for genetic heterogeneity. Hum Genet 1995;95:5662.

4 Van Schothorst EM, Jansen, JC, Bardoel AFJ, et al. Confinement of PGL, an imprinted gene causing hereditary paragangliomas, to a $2 \mathrm{cM}$ interval on $11 \mathrm{q} 22-\mathrm{q} 23$ and exclusion of DRD2 and NCAM as candidate genes. Eur 7 Hum Genet 1996;4:267-73.

5 Baysal BE, vanSchothorst EM, Farr JE, et al. A high resolution physical map of the hereditary paraganglioma region on chromosmal band 11q23; evaluation of the candidate genes and characterisation of new polymorphisms. Am $\mathcal{F}$

6 Scrable H, Cavenee W, Ghavimi F, et al. A model for embryonal rhabdomyosarcoma tumorigenesis that involves genome imprinting. Proc Natl Acad Sci USA 1989;86: $7480-4$. 
7 Williams JC, Brown KW, Mott MG, et al. Maternal allele loss in Wilms' tumour. Lancet 1989;1:283-4.

8 Scott J, Cowell J, Robertson ME, et al. IGF-II gene expression in Wilms tumour and embryonic tissues. Nature 1985 317:260-2.

9 Yun K, Molenaar AJ, Fiedler AM, et al. Insulin like growth factor II messenger RNA expression in Wilms tumour, nephrogenic rest and kidney. Lab Invest 1993;69:603-15.

10 Rainier S, Johnson LA, Dobry CJ, et al. Relaxation of imprinted genes in human cancer. Nature 1993;362:747-9.

11 Ogawa O, Eccles MR, Szeto J, et al. Relaxation of insulin-like growth factor II gene imprinting in Wilms' tumour. Natur 1993;362:749-51.

12 Steenman M, Rainier S, Dobry CJ, et al. Loss of imprinting of IGF2 is linked to reduced expression and abnormal methylation of H19 in Wilms tumour. Nat Genet 1994;7 433-9.

13 Moulton T, Crenshaw T, Hao Y, et al. Epigenetic lesions at the H19 gene in Wilms tumour patients. Nat Genet 1994;7: $440-7$.

14 Hatada I, Inazawa J, Abe T, et al. Genomic imprinting of human $\mathrm{p} 57^{\mathrm{KIP} 2}$ and its reduced expression in Wilms tumors. Hum Mol Genet 1996;5:783-8.

15 Thompson JS, Reese KJ, Debaun MR, et al. Reduced expression of the cyclin-dependent kinase inhibitor gene p57 ${ }^{\mathrm{KIP} 2}$ in Wilms' tumor. Cancer Res 1996;56:5723-7.

16 Liu JQ, Kahri AI, Heikkila P, et al. Ribonucleic acid expression of the clustered imprinted genes, p57 (KIP2), insulinlike growth factor II, and H19, in adrenal tumors and cultured adrenal cells. F Clin Endocrinol Metab 1997;82:176671 .

17 Ilvesmaki V, Kahri AI, Miettinen PJ, et al. Insulin-like growth factors (IGFs) and their receptors in adrenal growth factors (IGFs) and their receptors in adrenal tumors: high IGF-II expression in functional adrenocorti-

18 Seizinger BR, Klinger HP, Junien C, et al. Report on the commitee on chromosome and gene loss in human neoplasia. Cytogenet Cell Genet 1991;58:1080-96.

19 Gicquel C, RaffinSanson ML, Gaston V, et al. Structural and functional abnormalities at $11 \mathrm{p} 15$ are associated with the malignant phenotype in sporadic adrenocortical tumors: study on a series of 82 tumors. F Clin Endocrinol Metab 1997;82:2559-65.

20 Casola S, Pedone PV, Cavazzana AO, et al. Expression and parental imprinting of the $\mathrm{H} 19$ gene in human rhabdomyoparental imprinting of the H19 gene in

21 Visser M, Sijmons C, Bras J, et al. Allelotype of pediatric rhabdomyosarcoma Oncogene 1997;11:1309-14.

22 Zhan SL, Shapiro DN, Helman LJ. Activation of an imprinted allele of the insulin-like growth factor-II gene implicated in rhabdomyosarcoma. $\mathcal{F}$ Clin Invest 1994;94: $445-8$.

23 Minniti CP, Tsokos M, Newton WA, et al. Specific expression of insulin-like growth factor II in rhabdomyosarcoma tumor cells. Am F Clin Pathol 1994;101:198-203.

24 Albrecht S, von Schweinitz D, Waha A, et al. Loss of maternal alleles on chromosome arm $11 \mathrm{p}$ in hepatoblastoma. nal alleles on chromosome
Cancer Res 1994;54:5041-4.

$25 \mathrm{Li} \mathrm{X}$, Adam G, Cui B, et al. Expression, promoter usage and parental imprinting status of insulin-like growth factor II (IGF2) in human hepatoblastoma: uncoupling of IGF2 and H19 imprinting. Oncogene 1995;11:221-9.

26 Little MH, Thomson DB, Hayward NK. Loss of alleles on the short arm of chromosome 11 in a hepatoblastoma from a child with Beckwith-Wiedemann syndrome. Hum Genet 1988;79:186-9.

27 Ariel I, Ayesh S, Perlman EJ, et al. The product of the imprinted H19 gene is an oncofetal RNA. F Clin Pathol: Mol Pathol 1997;50:34-44.

28 De Souza AT, Hankins GR, Washington MK, et al. M6P/IGF2R gene is mutated in human hepatocellular carcinomas with loss of heterozygosity. Nat Genet 1995;11: 447-9.

29 Yamada T, DeSouza AT, Finkelstein S, et al. Loss of the gene encoding mannose 6-phosphate insulin-like growth factor II receptor is an early event in liver carcinogenesis. Proc Natl Acad Sci USA 1997;94:10351-5.

30 De Souza AT, Hankins GR, Washington MK, et al. Frequent loss of heterozygosity on $6 \mathrm{q}$ at the mannose 6-phosphate/insulin-like growth factor II receptor locus in human hepatocellular tumors. Oncogene 1995;10:1725-9.

31 Kim KS, Lee Y1. Biallelic expression of the H19 and IGF2 genes in hepatocellular carcinoma. Cancer Lett 1997;119. 143-8.

32 Hankins GR, DeSouza AT, Bentley RC, et al. M6P/IGF2 receptor: a candidate breast tumor suppressor gene. Oncogene 1996;12:2003-9.

33 Tran YK, Newsham IF. High-density marker analysis of 11 p15.5 in non-small cell lung carcinomas reveals allelic detection of one shared and one distinct region when compared to breast carcinomas. Cancer Res 1996;56:2916-21.

34 McCann AH, Miller N, O'Meara A, et al. Biallelic expression of the IGF2 gene in human breast disease. Hum Mol Genet 1996;5:1123-7.

35 Wu HK, Squire JA, Catzavelos CG, et al. Relaxation of imprinting of human insulin-like growth factor II gene, IGF2, in sporadic breast carcinomas. Biochem Biophys Res Commun 1997;235:123-9.

36 Karnik P, Paris M, Williams BRG, et al. Two distinct tumor suppressor loci within chromosome $11 \mathrm{p} 15$ implicated in breast cancer progression and metastasis. Hum Mol Gene 1998;7:895-908.
37 Kondo M, Matsuoka S, Uchida K, et al. Selective maternal allele loss in human lung cancers of the maternally $1365-8$

38 Kondo M, Suzuki H, Ueda R, et al. Frequent loss of imprinting of the $\mathrm{H} 19$ gene is often associated with its overexpression in human lung cancers. Oncogene 1995;10: 1193-8

39 Kondo M, Suzuki H, Ueda R, et al. Parental origin of $11 \mathrm{p} 15$ deletions in human lung cancer. Oncogene 1994;9:3063-5. 0 Suzuki H, Ueda R, Takahashi T, et al. Altered imprinting in lung cancer. Nat Genet 1994;6:332-3.

41 Virmani AK, Fong KM, Kodagoda D, et al. Allelotyping demonstrates common and distinct patterns of chromosomal loss in human lung cancer types. Genes Chromosomes Cancer 1998;21:308-19.

42 Ouyang $\mathrm{H}$, Shiwaku HO, Hagiwara $\mathrm{H}$, et al. The insulin-like growth factor II receptor gene is mutated in genetically unstable cancers of the endometrium, stomach and colorectum. Cancer Res 1997;57:1851-4.

43 Kinouchi Y, Hiwatashi N, Higashioka S, et al. Relaxation of imprinting of the insulin-like growth factor-II gene in colorectal cancer. Cancer Lett 1996;107:105-8.

$44 \mathrm{Vu} \mathrm{TH}$, Yballe C, Boonyanit S, et al. IGF-II in uterine smooth muscle tumours: maintenance of genomic imprinting in leiomyomata and loss in leiomyosarcomata. $\mathcal{F}$ Clin Endocrinol Metab 1995;80:849-59.

45 van Gurp RJHLM Oosterhuis JW, Kalscheuer V, et al. Biallelic expression of the H19 and IGF2 genes in human tes-
ticular germ cell tumors. $\mathcal{F}$ Natl Cancer Inst 1994;86:10705 .

46 Verkerk A, Ariel I, Dekker MC, et al. Unique expression patterns of $\mathrm{H} 19$ in human testicular cancers of different etiology. Oncogene 1997;14:95-107.

47 Oda H, Kume H, Shimizu Y, et al. Loss of imprinting of IGF2 in renal cell carcinoma. Int $\mathcal{F}$ Cancer 1998;75:343-6.

48 Morito R, Saito S, Ishikawa J, et al. Common regions of deletion on chromosomes $5 \mathrm{q}, 6 \mathrm{q}$, and $10 \mathrm{q}$ in renal cell carcinoma. Cancer Res 1991;51:5817-20.

49 Sohda T, Soejima H, Matsumoto T, et al. Insulin-like growth factor 2 gene imprinting in clear cell sarcoma of the kidney. Hum Pathol 1998;28:1315-18.

50 Lustig-Yarev O, Schulze E, Komitowski D, et al. The expression of the imprinted genes H19 and IGF-2 in choriocarinoma cell lines. Is H19 a tumor suppressor gene? Oncogene 1997;15:169-77.

51 Rachmilewitz J, Elkin M, Rosensaft J, et al. H19 expression and tumorigenicity of choriocarcinoma derived cell lines. Oncogene 1995;11:863-70.

52 Hashimoto KAC, Koyama M, Ohashi K, et al. Loss of imprinting in choriocarcinoma. Nat Genet 1995;9:109-10.

53 Walsh C, Miller SJ, Flam F, et al. Paternally derived H19 is differentially expressed in malignant and nonmalignant trophoblast. Cancer Res 1995;55:1111-16.

54 Douc-Rasy S, Barrios M, Fogel S, et al. High incidence of loss of heterozygosity and abnormal imprinting of $\mathrm{H} 19$ and IGF2 genes in invasive cervical carcinomas. Uncoupling of H19 and IGF2 expression and biallelic hypomethylation of H19. Oncogene 1996;12:423-30.

55 Muliokandov MR, Kholodilov MG, Atkin NB, et al. Genomic alterations in cervical carcinoma-losses of chromosome heterozygosity and human papilloma virus tumor status. Cancer Res 1996;56:197-205.

56 Hibi K, Nakamura H, Hirai A, et al. Loss of H19 imprinting in esophageal cancer. Cancer Res 1996;56:480-2.

57 Mori $M$, Inoue $\mathrm{H}$, Shiraishi $\mathrm{T}$, et al. Relaxation of insulin-like growth factor 2 gene imprinting in esophageal cancer. Int F Cancer 1996;68:441-6.

58 Cooper MJ, Ficher M, Komitowski D, et al. Developmentally imprinted genes as markers for bladder tumor progression. F Urol 1996;155:2120-7.

59 Wu HK, Weksberg R, Minden MD, et al. Loss of imprinting of human insulin-like growth factor II gene, IGF2, in acute myeloid leukemia. Biochem Biophys Res Commun 1997;231: 466-72.

60 Souza RF, Appel R, Yin J, et al. Microsatellite instability in the insulin-like growth factor II receptor in gastrointestinal tumors. Nat Genet 1997;14:255-7.

61 Wu MS, Wang HP, Lin CC, et al. Loss of imprinting and overexpression of IGF2 gene in gastric adenocarcinoma. Cancer Lett 1997;120:9-14.

62 Queimado L, Seruca R, Costapereira A, et al. Identification of 2 distinct regions of deletion at $6 \mathrm{q}$ in gastric carcinoma. Genes Chromosomes Cancer 1995;14:28-34.

63 Debiecrychter M, Alwasiak J, Liberski PP, et al. Accumulation of chromosomal changes in human glioma progression - a cytogenetic study of 50 cases. Cancer Genet Cytogenet 1997;75:1831-5.

64 Uyeno S, Aoki Y, Nata M, et al. IGF2 but not H19 shows loss of imprinting in human glioma. Cancer Res 1996;56: $5356-9$

65 Saito S, Salto H, Koi S, et al. Fine-scale deletion mapping of the distal long arm of chromosome 6 in 70 human ovarian cancers. Cancer Res 1992;52:5815-17.

66 Yun K, Fukumoto M, Jinno Y. Monoallelic expression of the insulin-like growth factor-II gene in ovarian-cancer. $A m f$ Pathol 1996;148:1081-7.

67 Wada M, Seeger RC, Mizoguchi H. Maintenance of normal imprinting of H19 and IGF2 genes in neuroblastoma. Cancer Res 1995;55:3386-8.

68 Knudsen AG, Strong LC. Mutation and cancer: statistical study of retinoblastoma. Proc Natl Acad Sci USA 1971;68: $820-3$. 
69 Dowdy, SF, Fasching, CL, Araujo D, et al. Suppression of tumourigenicity in 'Wilms' tumour by the p15.5-p14 region of chromosome 11 . Science 1991;254:293-5.

70 Koi MJL, Kalikin LM, Little PFR, et al. Tumor cell growth arrest caused by subchromosomal transferable DNA fragments from chromosome 11. Science 1993;260:361-4

71 Reid LH, West A, Gioeli DG, et al. Localisation of a tumour suppressor gene in $11 \mathrm{p} 15.5$ using the G401 Wilms' tumour cell assay. Hum Mol Genet 1996;5:239-47.

72 Werner H, LeRoith $\mathrm{D}$. The role of the insulin-like growth factor system in human cancer. Adv Cancer Res 1996;68: $183-223$.

73 Rubin R, Baserga R. IGF-I receptor. Lab Invest 1995;73: 311-31.

74 Ogawa O, Mc Noe LA, Eccles MR, et al. Human insulin-like growth factor type I and type II receptors are not imprinted. Hum Mol Genet 1993;2:2163-5.

75 Sell C, Rubini M, Rubin R, et al. Simian virus 40 large tumor antigen is unable to transform mouse embryonic tumor antigen is unable to transform mouse embryonic receptor. Proc Natl Acad Sci USA 1993;90:11217-21.

76 Schofield PN. The IGFs in cell growth and transformation. In: Gorin N, ed. Education programme of the European haematology association. Oxford: Blackwell, 1996:112-17.

77 Christofori G, Naik P, Hanahan D. A second signal supplied by insulin-like growth factor II in oncogene-induced tumorigenesis. Nature 1994;369:414-18.

78 DeChiara TM, Robertson EJ, Efstratiadis A. Parental imprinting of the mouse insulin-like growth factor II gene. Cell 1991;64:849-59.

79 Ohlsson R, Nystrom A, Pfeifer-Ohlsson S, et al. IGF2 is parentally imprinted during human embrogenesis and in the Beckwith Wiedemann syndrome. Nat Genet 1993;4:94 7.

80 Giannoukakis N, Deal C, Paquette J, et al. Parental genomic imprinting of the human IGF2 gene. Nat Genet 1993;4:98101 .

81 Taniguchi $\mathrm{T}$, Sullivan $\mathrm{MJ}$, Ogawa $\mathrm{O}$, et al. Epigenetic changes encompassing the IGF2/ H19 locus associated changes encompassing the $\mathrm{IGF} 2 / \mathrm{H} 9$ locus associated Wilms tumor. Proc Natl Acad Sci USA 1995;92:2159-63.

82 Weksberg R, Shen DR, Fei YL, et al. Disruption of insulinlike growth factor 2 imprinting in Beckwith-Wiedemann like growth factor 2 imprinting in Bec

83 Joyce JA, Lam WK, Catchpoole DJ, et al. Imprinting of IGF2 and H19: lack of reciprocity in sporadic Beckwith Wiedemann syndrome. Hum Mol Genet 1997;6:1543-8.

84 Wang WH, Duan JX, Vu TH, et al. Increased expression of the insulin-like growth factor II gene in Wilms' tumor is not dependent on loss of genomic imprinting or loss of heterozygosity. F Biol Chem 1996;271:27863-70.

85 Davies S. Maintenance of genomic imprinting at the IGF2 locus in hepatoblastoma. Cancer Res 1993;53:4781-3.

86 Zhan S, Shapiro DN, Helman LJ. Loss of imprinting of IGF2 in Ewing's sarcoma. Oncogene 1995;11:2503-7.

87 Pedone PV, Tirabosco R, Cavazzana AO, et al. Mono- and bi-allelic expression of insulin-like growth factor II in human muscle tumors. Hum Mol Genet 1994;3:1117-21.

88 Gloudemans T, Prinsen I, Vannounik JAM, et al. Insulinlike growth factor gene expression in human smooth muslike growth factor gene expression in hum

89 Zhang Y, Tycko B. Monoallelic expression of the human H19 gene. Nat Genet 1992;1:40-4.

90 Hao Y, Crenshaw T, Moulton T, et al. Tumour-suppressor activity of H19 RNA. Nature 1993;365:764-7.

91 Brannan CI, Dees EC, Ingram RS, et al. The product of the H19 gene may function as an RNA. Mol Cell Biol 1990;10: $28-36$.

92 Bartolomei MS, Webber AL, Brunkow ME, et al. Epigenetic mechanisms underlying the imprinting of the mouse $\mathrm{H} 19$ gene. Genes Dev 1993;7:1663-73.

93 Lee MH, Reynisdotter I, Massague J. Cloning of $\mathrm{p} 57^{\mathrm{KIP} 2}$, a cyclin-dependent kinase inhibitor with unique domain structure and tissue distribution. Genes Dev 1995;9:639structur 49.

94 Matsuoka S, Edwards MC, Bai C, et al. p57 $7^{\mathrm{KIP} 2}$, a structurally distinct member of the p21CIP1 CDK inhibitor family, is a candidate tumor suppressor gene. Genes Dev 1995;9: $650-662$.

95 Hatada I, Mukai T. Genomic imprinting of $\mathrm{p} 57^{\mathrm{KIP} 2}$, a cyclin dependent kinase inhibitor in mouse. Nat Genet 1995;11: $204-6$.
96 Cost GJ, Thompson JS, Reichard BA, et al. Lack of imprinting of three human cyclin-dependent kinase inhibitor genes. Cancer Res 1997;57:926-9.

97 Watanabe H, Pan ZQ, SchreiberAgus N, et al. Suppression of cell transformation by the cyclin-dependent kinase inhibitor $\mathrm{p} 57^{(\mathrm{KIP} 2)}$ requires binding to proliferating cell nuclear antigen. Proc Natl Acad Sci USA 1998;95:1392-7.

98 Overall ML, Spencer J, Bakker M, et al. p $57^{\mathrm{KIP} 2}$ is expressed in Wilms' tumor with LOH of $11 \mathrm{p} 15.5$. Genes Chromosomes Cancer 1996;17:56-9.

99 Orlow I, Iavarone A, Cridermiller SJ, et al. Cyclindependent kinase inhibitor $\mathrm{p} 57^{\mathrm{KIP} 2}$ in soft-tissue sarcomas nd Wilms' tumors. Cancer Res 1996;56:1219-21.

100 Tokino T, Urano T, Furuhata T, et al. Characterization of the human $\mathrm{p} 57^{\mathrm{KIP} 2}$ gene-alternative splicing, insertion deletion polymorphisms in VNTR sequences in the coding region, and mutational analysis. Hum Genet 1996;97:62531 .

101 Bonilla F, Orlow I, CordonCardo C. Mutational study of p16 (CDKN2/MTS1/INK4A) and p5 $7^{\mathrm{KIP} 2}$ genes in hepatocellular carcinoma. Int $\mathcal{F}$ Oncol 1998;12:583-8.

102 Hatada I, Ohashi H, Fukushima Y, et al. An imprinted gene $\mathrm{p} 57^{\mathrm{KIP} 2}$ is mutated in Beckwith-Wiedemann syndrome. Nat Genet 1996;14:171-3.

103 O'Keefe D, Dao D, Zhao L, et al. Coding mutations in p5 $7^{\mathrm{KIP} 2}$ are present in some cases of Beckwith-Wiedemann syndrome but are rare or absent in Wilms' tumors. Am 7 Hum Genet 1997;61:295-303.

104 Lee MP, DeBaun M, Randhawa G, et al. Low frequency of p $57^{\mathrm{KIP} 2}$ mutation in Beckwith-Wiedemann syndrome. Am 7 Hum Genet 1997;61:304-9.

105 Reid LH, Cridermiller SJ, West A, et al. Genomic organisation of the human $\mathrm{p} 57^{\mathrm{KIP} 2}$ gene and its analysis in the G401 Wilms' tumor assay. Cancer Res 1996;56:121418 .

106 Qian N, Frank D, O'Keefe D, et al. The IPL gene on chromosome $11 \mathrm{p} 15.5$ is imprinted in humans and mice and is similar to TDAG51, implicated in Fas expression and apoptosis. Hum Mol Genet 1997;6:2021-9.

107 Lee MP, Feinberg AP. Genomic imprinting of a human apoptosis gene homologue, TSSC3. Cancer Res 1998;58: $1052-6$

108 Schweinbacher C, Sabbioni S, Campi M, et al. Transcriptional map of $170-\mathrm{kb}$ region at chromosome $11 \mathrm{p} 15.5$ : identification and mutational analysis of the BWR1A gene reveals the presence of mutations in tumor samples. Proc Natl Acad Sci USA 1998;95:3873-8

109 Sabbioni S, Barbanti-Brodano G, Croce CM, et al. GOK: a gene at 11 p15 involved in rhabdomyosarcoma and rhabdoid tumor development. Cancer Res 1997;60:4493-7.

110 Horsthemke B. Structure and function of the human chromosome 15 imprinting center. F Cell Physiol 1997;173:237-

111 Barlow DP, Stoger R, Herrmann BG, et al. The mouse insulin-like growth-factor type-2 receptor is imprinted and closely linked to the Tme locus. Nature 1991;349:84-7.

$112 \mathrm{Xu}$ YQ, Goodyer CG, Deal C, et al. Functional polymorphism in the parental imprinting of the human IGF2R gene. Biochem Biophys Res Commun 1993;197:747-54.

113 Lau MMH, Stewart CEH, Liu ZY, et al. Loss of the imprinted IGF2/cation-independent mannose 6-phosphate Genes Dev 1994;8:2953-63.

114 de Bleser PJ, Jannes P, van Buul-Offeres SC, et al. Insulinlike growth factor-II/mannose 6-phosphate receptor is expressed on $\mathrm{CCl}_{4}$-exposed rat fat storing cells and facilitates activation of latent transforming growth factorbeta in cocultures with sinusoidal endothelial cells. Hepatology 1995;21:1429-37.

115 Wang K, Souza RF, Kong D, et al. Deficient transforming growth factor- $\beta 1$ activation and excessive insulin-like growth factor II (IGFII) expression in IGFII receptormutant tumors. Cancer Res 1997;57:2543-6.

116 Jinno Y, Yun K, Nishiwaki K, et al. Mosaic and polymorphic imprinting of the WT1 gene in humans. Nat Genet 1994;6:305-9.

117 XuYQ, Grundy P, Polychronakos C. Aberrant imprinting of the insulin-like growth factor II receptor gene in Wilms tumor. Oncogene 1997;14:1041-6. 